\title{
The Time Course of Dopamine Transmission in the Ventral Tegmental Area
}

\author{
Christopher P. Ford, ${ }^{1}$ Paul E. M. Phillips, ${ }^{2,3}$ and John T. Williams ${ }^{1}$ \\ ${ }^{1}$ Vollum Institute, Oregon Health \& Science University, Portland, Oregon 97239, and Departments of ${ }^{2}$ Psychiatry and Behavioral Sciences and \\ 3Pharmacology, University of Washington, Seattle, Washington 98195
}

Synaptic transmission mediated by G-protein coupled receptors (GPCR) is not generally thought to be point-to-point. To determine the extent over which dopamine signals in the midbrain, the present study examined the concentration and time course of dopamine that underlies a $\mathrm{D}_{2}$-receptor IPSC ( $\mathrm{D}_{2}$-IPSC) in the ventral tegmental area. Extracellular dopamine was measured electrochemically while simultaneously recording $\mathrm{D}_{2}$-IPSCs. The presence of dopamine was brief relative to the IPSC, suggesting that G-protein dependent potassium channel activation determined the IPSC time course. The activation kinetics of $\mathrm{D}_{2}$ receptor-dependent potassium current was studied using outside-out patch recordings with rapid application of dopamine. Dopamine applied at a minimum concentration of $10 \mu \mathrm{M}$ for a maximum of $100 \mathrm{~ms}$ mimicked the IPSC. Higher concentrations applied for as little as $5 \mathrm{~ms}$ did not change the kinetics of the current. The results indicate that both the intrinsic kinetics of G-protein coupled receptor signaling and a rapidly rising high concentration of dopamine determine the time course of the IPSC. Thus, dopamine transmission in the midbrain is more localized then previously proposed.

\section{Introduction}

The time course of synaptic transmission is determined by the kinetics of receptor activation, the concentration of neurotransmitter, and the clearance of transmitter from the synapse (Katz and Miledi, 1973; Lester et al., 1990; Barbour et al., 1994; Diamond and Jahr, 1995, 1997; Balakrishnan et al., 2009). Two distinct classes of receptors mediate transmission: ligand-gated ion channels and metabotropic G-protein coupled receptors (GPCRs). Fast synaptic currents mediated by ligand-gated ion channels result from a rapid rise and fall $(\sim 1 \mathrm{~ms})$ of a high concentration $(\mathrm{mM})$ of transmitter (Clements et al., 1992; Barbour et al., 1994; Diamond and Jahr, 1997; Overstreet et al., 2000; Mozrzymas et al., 2003; Beato, 2008). Less clear, however, is the concentration and time course of transmitter that mediates synaptic currents through the activation of GPCRs.

In numerous regions, a variety of GPCRs mediate IPSCs through G-protein coupled potassium channels (GIRK/Kir3) channels (Lüscher et al., 1997; Sodickson and Bean, 1998). The activation of these channels occurs with a time constant of several hundred milliseconds following a lag to onset of $\sim 50 \mathrm{~ms}$ (Logothetis et al., 1987; Wickman et al., 1994; Huang et al., 1995; Kofuji et al., 1995; Sodickson and Bean, 1996; Ingram et al., 1997; Riven et al., 2006). Despite the slow intrinsic signaling between GPCRs and the potassium conductance, the kinetics of IPSCs mediated by these receptors are highly sensitive to the block of metabolism or re-

Received July 22, 2009; revised Sept. 17, 2009; accepted Sept. 18, 2009.

This work was supported by National Institutes of Health Grants K99DA026417 (C.P.F.), DA04523 (J.T.W.), DA17155 (P.E.M.P.), and DA24140 (P.E.M.P.). C.P.F. was the Wyeth Fellow of the Life Sciences Research Foundation and a fellow of the Alberta Heritage Foundation for Medical Research. J.T.W. was a National Alliance for Research on Schizophrenia and Depression Ritter Foundation Investigator. We thank C. E. Jahr for advice and support with the rapid application of dopamine and A. C. Riegel, S. T. Hentges, and C. E. Jahr for critical advice on this manuscript.

Correspondence should be addressed to John T. Williams, Vollum Institute, Oregon Health \& Science University L474, 3181 SW Sam Jackson Park Road, Portland, OR 97239. E-mail: williamj@ohsu.edu.

DOI:10.1523/JNEUROSCI.3546-09.2009

Copyright $\odot 2009$ Society for Neuroscience ～0270-6474/09/2913344-09\$15.00/0 uptake of transmitter (Isaacson et al., 1993; Beckstead et al., 2004). Thus, although GPCR-mediated IPSCs have been well described (Otis and Mody, 1992; Isaacson et al., 1993; Kulik et al., 2002), the mechanisms that determine the time course of transmission through this pathway is not completely understood.

Dendritic release of dopamine from neurons in the substantia nigra $(\mathrm{SNc})$ and ventral tegmental area (VTA) has been studied over many years (Björklund and Lindvall, 1975; Geffen et al., 1976; Wilson et al., 1977; Cheramy et al., 1981; Nirenberg et al., 1996; Rice et al., 1997; Jaffe et al., 1998). Recent work indicates that dendritic dopamine release activates $\mathrm{D}_{2}$ receptors to produce an IPSC via activation of GIRK channels (Beckstead et al., 2004). The time course of the dopamine-dependent IPSC is, however, short relative to reports on the presence of extracellular dopamine (Chen and Rice, 2001; Chen et al., 2006). This raises the possibility that the prolonged, low concentrations of extracellular dopamine may not represent the time course and concentration of dopamine underlying transmission.

Using the combination of electrochemistry and electrophysiology, the present study compared the time course of the rise and fall of dopamine and the dopamine IPSC in the VTA. Recordings of the current induced by dopamine in outside-out patches from dopamine cells were used to define the intrinsic kinetics of the $\mathrm{D}_{2}$-receptor dependent activation of GIRK channels. The results indicate that the concentration of dopamine required to activate a $\mathrm{D}_{2}$-receptor dependent IPSC is surprisingly high and the rise and fall of dopamine in the extracellular space is faster than previously reported.

\section{Materials and Methods}

Slice preparation and visualization. Horizontal slices $(220 \mu \mathrm{m})$ of midbrain from male and female DBA/2J mice (4-8 week old, Jackson Laboratories) were cut in ice-cold physiological saline solution containing (in mM) $126 \mathrm{NaCl}, 2.5 \mathrm{KCl}, 1.2 \mathrm{MgCl}_{2}, 2.4 \mathrm{CaCl}_{2}, 1.4 \mathrm{NaH}_{2} \mathrm{PO}_{4}, 25$ 
$\mathrm{NaHCO}_{3}, 11$ D-glucose, and $0.005 \mathrm{MK}-801$ using a Vibratome (Leica). Slices were incubated in warm $\left(35^{\circ} \mathrm{C}\right) 95 \% \mathrm{O}_{2} / 5 \% \mathrm{CO}_{2}$ oxygenated saline containing MK-801 $(10 \mu \mathrm{M})$ for at least $30 \mathrm{~min}$ and transferred to a chamber that was constantly perfused $(1.5 \mathrm{ml} / \mathrm{min})$ with oxygenated saline $\left(35^{\circ} \mathrm{C}\right)$. Slices were visualized with an Olympus BX51WI (Olympus America) microscope. Dopamine cells were classified as within the VTA, were medial to the medial lemniscus (Ford et al., 2006).

Electrophysiology. An Axopatch 200A amplifier (Molecular Devices) was used to make whole-cell recordings using $1.5-2.5 \mathrm{M} \Omega$ pipettes. $\mathrm{Pi}$ pette internal solution contained (in mM) $115 \mathrm{~K}$-methylsulphate, 20 $\mathrm{NaCl}, 1.5 \mathrm{MgCl}_{2}$, 5 HEPES, 10 BAPTA, 2 ATP, 0.3 GTP; pH 7.3, 270 $\mathrm{mOsm}$. Cells were voltage clamped at $-60 \mathrm{mV}$. Dopamine neurons were identified by established criteria for the identification of mesolimbic dopamine neurons in the mouse: (1) the presence of a $\mathrm{D}_{2}$-sensitive dopamine conductance, (2) pacemaker firing at $1-5 \mathrm{~Hz}$, (3) spike widths of $\geq 1.2 \mathrm{~ms}$, (4) input resistance $>400 \mathrm{M} \Omega$, and (5) input capacitance $>25$ pF (Ford et al., 2006; Lammel et al., 2008). Electrophysiological data were acquired using Axograph X (AxographX, Axograph Scientific). Series resistance was not compensated. Cells were discarded if the access resistance exceeded $10 \mathrm{M} \Omega$.

Dopamine release from the VTA was elicited with an extracellular mono-polar saline-filled glass electrode $(\sim 5 \mathrm{M} \Omega)$ placed $100-200 \mu \mathrm{m}$ from both the neuron being recorded and the tip of the exposed carbon electrode. As stated, either single pulses $(0.6 \mathrm{~ms})$ or trains $(0.5 \mathrm{~ms}$ at 40 $\mathrm{Hz})$ of stimuli $(\sim 30 \mu \mathrm{A})$ were used to drive dopamine release within the VTA. For the pharmacological isolation of the dopamine $\mathrm{D}_{2}$-receptor synaptic current $\left(\mathrm{D}_{2}\right.$-IPSC), the external solution contained picrotoxin $(100 \mu \mathrm{M})$, DNQX $(10 \mu \mathrm{M})$, CGP 55845 (200 nM), and MK-801 (10 $\mu \mathrm{M})$. BAPTA $(10 \mathrm{~mm})$ included in the internal solution was used to block mGluR signaling.

Fast-scan cyclic voltammetry. Glass encased carbon fiber electrodes with an exposed final length of 30-50 $\mu \mathrm{m}$ were prepared from $7 \mu \mathrm{m}$ diameter carbon fibers (34-700, Goodfellow). Before experimentation, the cut electrode tip was placed in isopropanol purified with activated carbon for $10 \mathrm{~min}$. The tip of the carbon fiber electrodes was placed in the slice $\leq 75 \mu \mathrm{m}$ below the neuron being recorded. Triangular waveforms (holding at $-0.4 \mathrm{~V})$ at $10 \mathrm{~Hz}(-0.4$ to $1.0 \mathrm{~V}$ vs $\mathrm{Ag} / \mathrm{AgCl}$ at $300 \mathrm{~V} / \mathrm{S}$ ) were used. Background subtracted cyclic voltammogram currents were obtained by subtracting 10 cyclic voltammograms (oxidation-reduction profiles) obtained before stimulation from voltammograms obtained after stimulation. After subtraction, two-dimensional voltammetric color plots were used to examine the data. To determine the time course of dopamine, the current at the peak oxidation $(\sim 600 \mathrm{mV})$ was plotted against time. After the experiment, the electrode was calibrated using dopamine solutions of known concentration.

To confirm the chemical identity of the fast-scan cyclic voltammetry (FSCV) signal, voltammograms from exogenously applied dopamine were compared to voltammograms obtained from evoked release. Dopamine was applied by the iontophoretic application of dopamine hydrochloride or serotonin hydrochloride (data not shown) as a single pulse (25-100 nA, 5-25 ms, [DA] $1 \mathrm{~m}$ ) from thin-walled iontophoretic electrodes $(70 \geq 100 \mathrm{M} \Omega)$. Iontophoretic electrodes were placed within 50 $\mu \mathrm{m}$ from the tip of the carbon fiber and a retention current of $1-5 \mathrm{nA}$ was applied to prevent passive leakage.

Constant potential amperometry. Amperometry was also used to monitor the evoked dopamine overflow as the kinetics of the presence of extracellular dopamine are faster than when observed with FSCV. Electrodes were fabricated and placed in the slice as for FSCV. A constant potential of $0.3 \mathrm{~V}$ was applied. The current was plotted at $80 \mathrm{~Hz}$, each data point was the average of 1000 points taken for $5 \mathrm{~ms}$. Ascorbate $(600 \mu \mathrm{M})$ was added to the external Krebs buffer to allow for the catalytic regeneration of dopamine. Ascorbic acid $(600 \mu \mathrm{M})$ prevents antioxidant depletion and stabilizes the catalysis of dopamine. Under these conditions, amperometry then detects individual analyte molecules multiple times. Thus, the resultant current is an indication of the concentration of dopamine in bulk solution. The rate of current change is dependent upon the radius of the diffusion layer maintained by ascorbic acid and the concentration of dopamine in the extracellular solution outside the diffusion layer (Venton et al., 2002). a single stim.
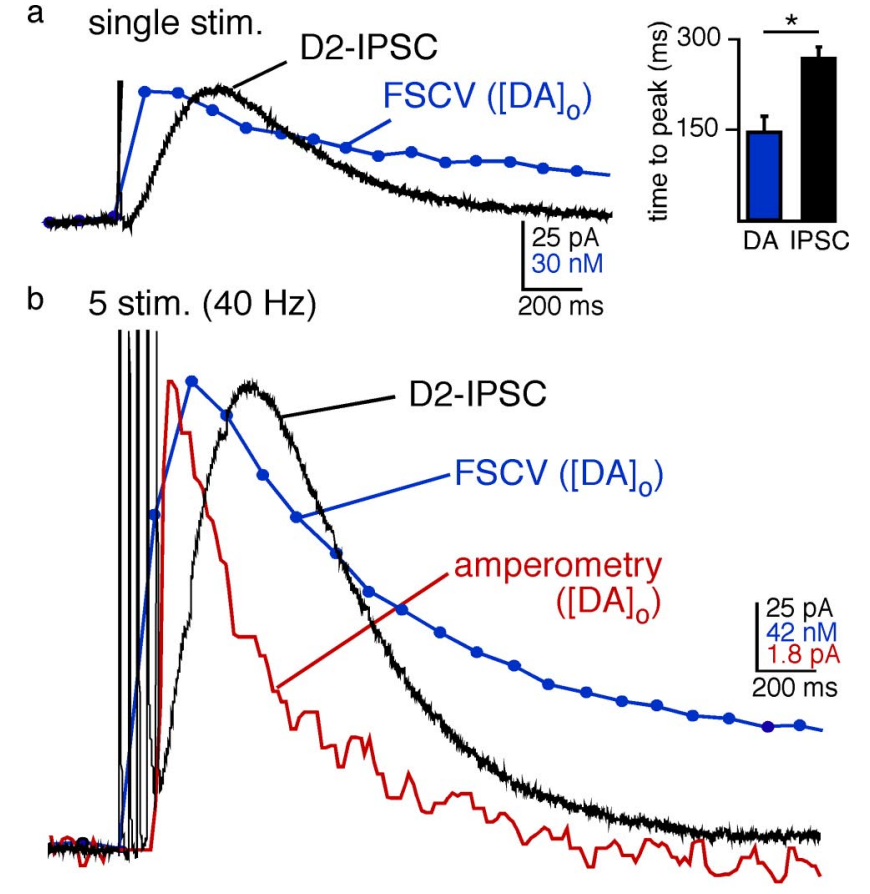

C

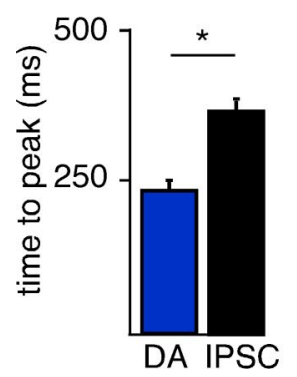

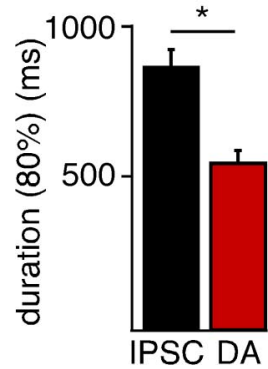

d
Figure 1. Comparing the time course of $[D A]_{0}$ and the $D_{2}-I P S C$. $\boldsymbol{a}$, Simultaneous recordings illustrating the change in $[D A]_{0}$ measured by $F S C V$ (blue trace average of recordings $n=17$ ) and a $D_{2}$-IPSC (black trace, trace is average of $n=17$ ) in the VTA. A single stimulus from an extracellular electrode in the VTA $(0.6 \mathrm{~ms})$ evoked a rapid rise in dopamine release and an IPSC. A triangular waveform ( $-0.4 \mathrm{~V}$ to $1.0 \mathrm{~V}$ at $300 \mathrm{~V} / \mathrm{S})$ was used to measure $[\mathrm{DA}]_{0}$ with FSCV. Waveform-induced artifacts in the electrophysiological trace were blanked. $\boldsymbol{b}$, Simultaneous measurements of changes in [DA $]_{0}$ by FSCV (traces are average of $n=17$ slices; blue trace) and amperometry (constant potential $=300 \mathrm{mV}, n=12$; red trace) and the $\mathrm{D}_{2}$-IPSC (black trace, $n=17$ cells) in the VTA evoked by a train of 5 stimuli $(40 \mathrm{~Hz})$.c, The time to peak of the IPSC was significantly longer than the time to peak for the increase in $[D A]_{0}$ measured by FSCV. The duration of the IPSC was also longer than the $[D A]_{0}$ measured by amperometry $\left({ }^{*} p<0.05\right)$. $\boldsymbol{d}$, Voltammograms from the peak of the FSCV $(n=9)$ matched well with those produced by the exogenous iontophoretic application of dopamine $(n=3)$, confirming that dopamine was oxidized by the carbon fiber following stimulation.

To estimate the extracellular time course of dopamine resulting from a single stimulation quantitative analysis of individual records were not possible due to the low signal-to-noise ratio. However, the group average $(n=17)$ approximated the time course of a $250 \mathrm{~ms}$ application of dopamine (normalized integral single stimulus $293 \mathrm{~mA} \mathrm{~S}^{-1}$; normalized integral $250 \mathrm{~ms}$ "open tip" potential $247 \mathrm{~mA} \mathrm{~S}^{-1}$ ).

Fast-flow dopamine application. Large nucleated macro patches were pulled from VTA dopamine cells using standard intracellular solution with standard patch pipettes $(\sim 1.3 \mathrm{M} \Omega)$. To obtain nucleated patches, gentle suction was applied over $\sim 1$ min until the nucleus was positioned directly at the tip of the patch pipette. While continually applying gentle suction, the patch pipette was slowly $(\sim 1 \mathrm{~min})$ pulled away from the cell. Care was taken to ensure that the nucleus remained positioned at the tip of the patch pipette. Separation of the nucleated patch from the cell was indicated by a rapid drop in the input capacitance (from $>25 \mathrm{pF}$ to $\sim 5$ 
$\mathrm{pF}$ ). Often obtaining nucleated patches was unsuccessful, such that small inside-out patches were pulled. To ensure that nucleated patches were pulled, access resistance was continuously monitored such that an access resistance $<5 \mathrm{M} \Omega$ was maintained. Nucleated patches were pulled out from the slice and placed in front of a theta-tube flow pipe that was situated in the bath $\sim 500 \mu \mathrm{m}$ above the slice. Once patches were pulled, solution was allowed to flow from the flow pipes. The bath volume was adjusted so that final $\sim 1 \mathrm{~cm}$ of the tip of the flow pipe was in contact with bath solution $\left(35^{\circ} \mathrm{C}\right)$. The flow rate was set to $\sim 50$ $\mu l$ per minute so that the temperature of the flow pipe solution reached equilibrium with that of the warmed bath solution. The flow pipe perfused two separate solutions: control containing in mм: $126 \mathrm{NaCl}, 2.5 \mathrm{KCl}, 1.2$ $\mathrm{MgCl}_{2}, 2.4 \mathrm{CaCl}_{2}, 1.4 \mathrm{NaH}_{2} \mathrm{PO}_{4} 0.6$ ascorbate, and a similar solution with a known concentration of dopamine. The flow pipe was attached to a piezoelectric bimorph. Passing $4.4 \mathrm{~V}$ across the bimorph could rapidly change the location of the tip of the flow pipe such that the solution passing over the patch could be rapidly switched from control to dopamine with rapid kinetics. To determine the kinetics, after each experiment, the patch was blown from the end of the pipette and the open tip current recorded between control solutions and test solution containing an additional $20 \mathrm{~mm}$ $\mathrm{NaCl}$ was measured, with the average $10-$ $90 \%$ rise time being $0.9+0.2 \mathrm{~ms}$.

Statistics and data analysis. Values listed are means \pm SEM. Statistical significance was assessed using either paired, or unpaired $t$ tests where appropriate. Normality of distribution was tested before running parametric $t$ tests. Paired comparisons were done with a Wilcoxon matched paired test. In cases where the distribution was not normal, a nonparametric Mann-Whitney $U$ test was used. A difference of $p<0.05$ was considered significant. Statistical tests were performed with InStat (GraphPad Software).

Materials. Quinpirole and CGP 55845 were obtained from Tocris Bioscience. Cocaine hydrochloride was obtained from National Institute on Drug Abuse-National Institutes of Health (Bethesda, MD). All other chemicals were obtained from Sigma-Aldrich.

\section{Results}

Receptor signaling limits the time course of metabotropic transmission

To relate the time course of the $\mathrm{D}_{2}$-IPSC to the presence of dopamine, simultaneous whole-cell voltage clamp and FSCV recordings were made in mouse brain slices containing the VTA. In the presence of antagonists to block $\mathrm{GABA}_{\mathrm{A}}, \mathrm{GABA}_{\mathrm{B}}$, AMPA, NMDA, and mGluR receptors, a single stimulation via an extracellular stimulating electrode evoked a $\mathrm{D}_{2}$-IPSC $(53.7 \pm 9 \mathrm{pA}, n=17)$. The IPSC was blocked by the $\mathrm{D}_{2}$-receptor antagonist sulpiride (data not shown), confirming that the current was mediated by $\mathrm{D}_{2}$ receptor activation (Beckstead et al., 2004; Ford et al., 2007). The time to peak of the $\mathrm{D}_{2}$-IPSC $(260 \pm 10 \mathrm{~ms})$ was slower than the

d
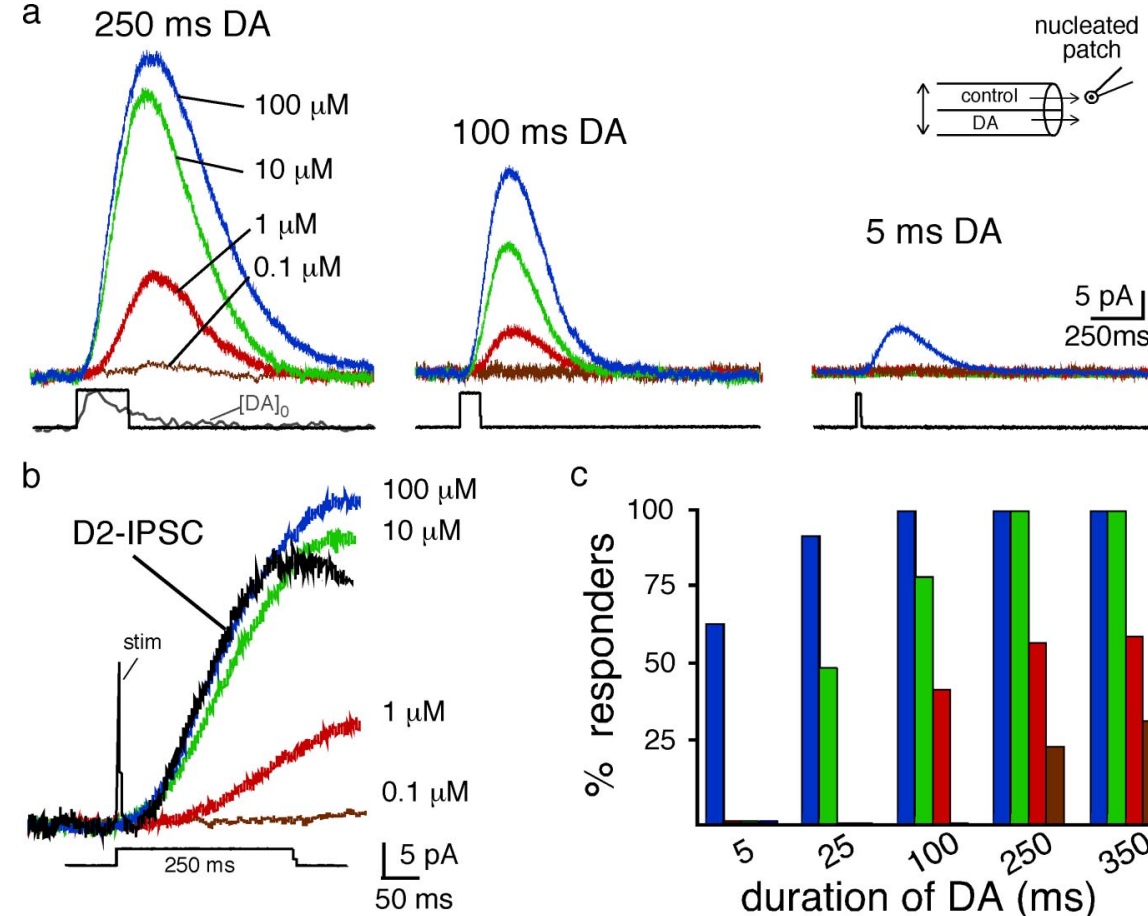

\section{$5 \mathrm{~ms}$ DA}

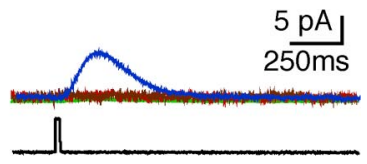

C
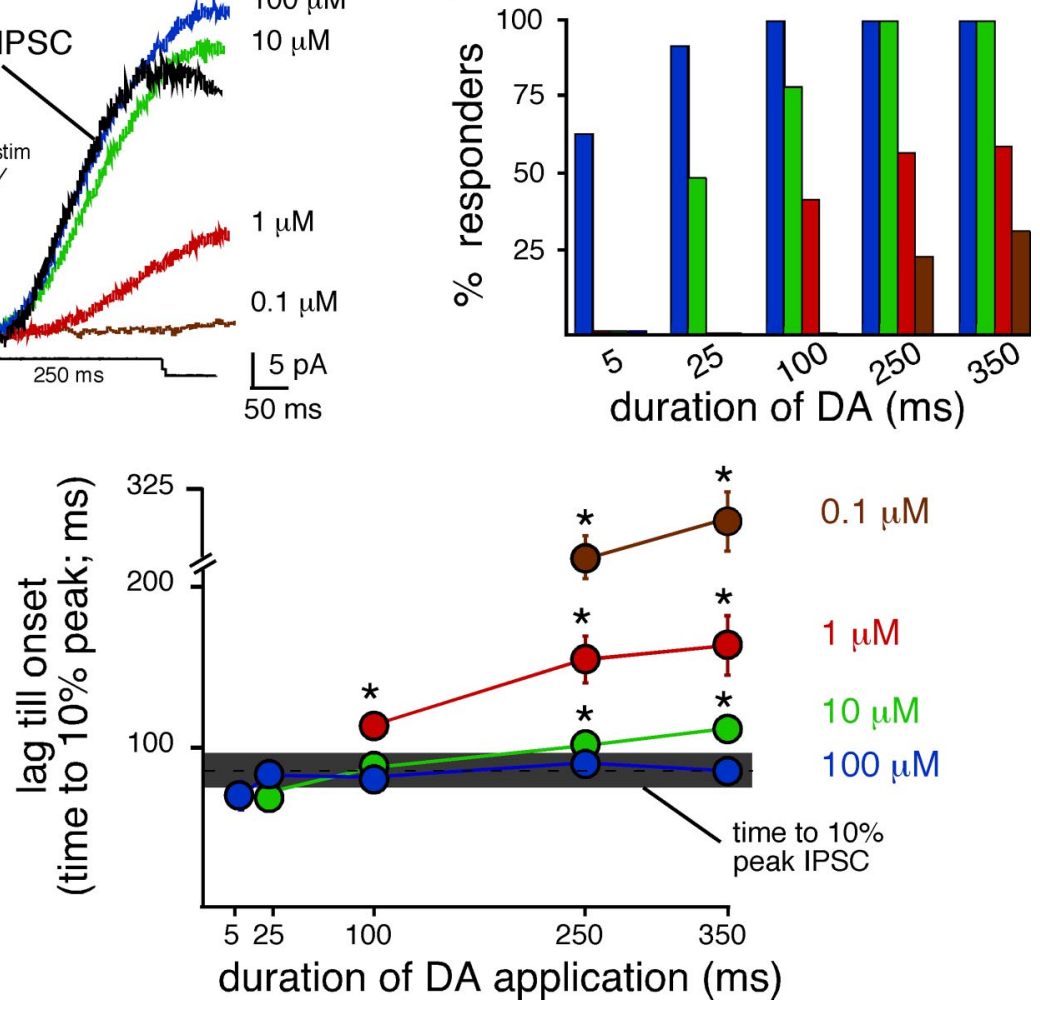

Figure 2. Currents elicited by the fast-flow application of dopamine to nucleated patches. $\boldsymbol{a}$, Representative recordings illustrating outward currents generated from rapid application of dopamine onto outside-out nucleated nucleated macro-patches. The amplitude of current increased as a function of concentration and duration. Dopamine was applied from a theta tube positioned directly in front of the nucleated patches (inset). Square pulses illustrated below are the open-tip current recorded as the junctioncurrent associated from switching the open pipette tip from control to solution of elevated $\mathrm{NaCl}$. Gray [DA] ${ }_{0}$ trace is the average of 17 traces of the amperometric current resulting from a single stimuli in the VTA. $\boldsymbol{b}$, Expanded traces illustrated in panel A for the 250 ms application of dopamine. Black trace is an example of a $\mathrm{D}_{2}$-IPSC evoked from a single pulse stimulus. Note that the current induced by dopamine (1 $\mu \mathrm{m}$ or $100 \mathrm{~nm}$ ) was slow to activate. Scale bar applies to all traces. c, Summarized data illustrating the proportion of patches where an outward current was obtained at each concentration and duration (responders). Colors represent blue: $100 \mu \mathrm{m}$, green: $10 \mu \mathrm{m}$, red: $1 \mu \mathrm{m}$ and brown: $100 \mathrm{~nm}$. $\boldsymbol{d}$, Summarized data illustrating the lag of activation of the outward current. The lag was determined as the time to reach $10 \%$ of the peak response between stimulation of an IPSC (horizontal gray bar) or the current induced by application of dopamine to nucleated patches. Horizontal gray bar represents the $95 \%$ confidence interval ( X2 SD) for the IPSC evoked from a single pulse.

concurrent rise in extracellular dopamine $(61 \pm 11 \mathrm{nM}, 144 \pm 15$ $\mathrm{ms}, n=17, p=0.002$ ) (Fig. 1a). The difference between the peak of the dopamine transient and the IPSC most likely represents the time required for metabotropic signaling (receptor/G-protein/ GIRK channel activation).

In vivo, dopamine neurons fire action potentials in a pacemaker or burst pattern (Grace and Onn, 1989). A train of 5 stimuli evoked larger IPSCs $(164 \pm 18 \mathrm{pA}, n=17)$ and increased the concentration of extracellular dopamine $(284 \pm 52 \mathrm{nM}, n=17)$ (Fig. 1b). The cyclic voltammograms (oxidation-reduction 
a a VTA DA soma

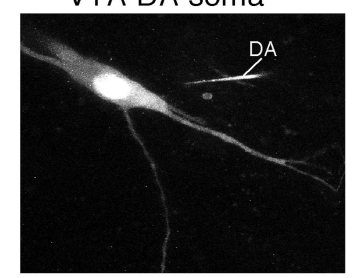

VTA DA dendrite

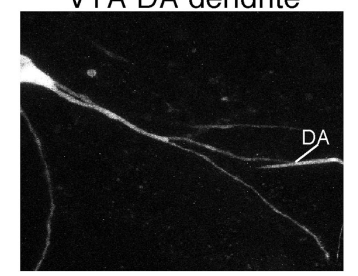

b
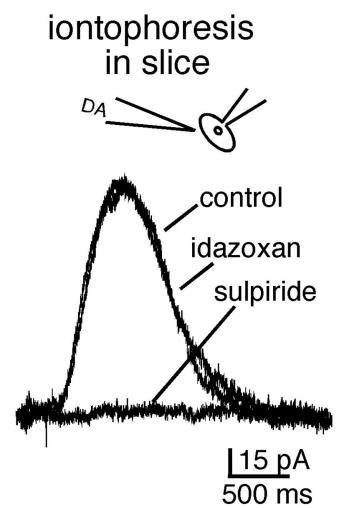

iontophoresis in slice

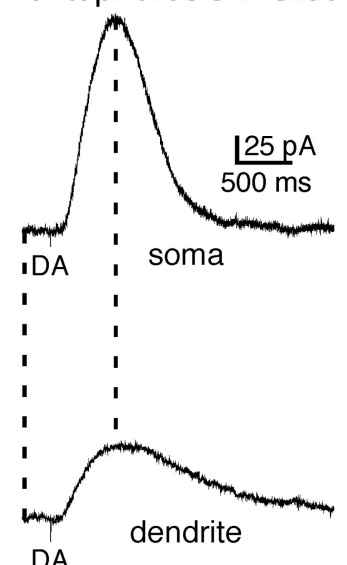

C
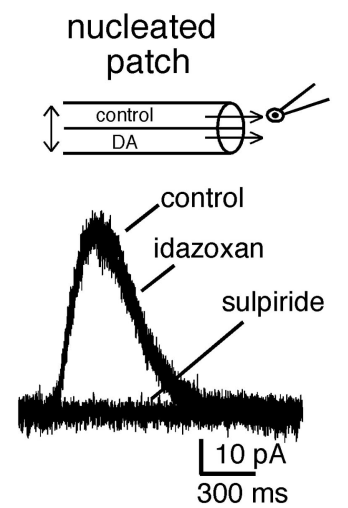
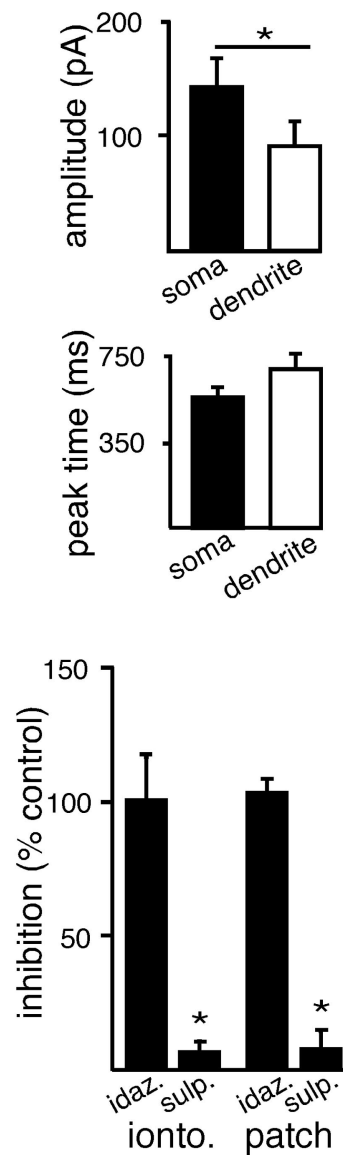

Figure 3. $D_{2}$-receptors mediate currents in the soma and dendrites $\boldsymbol{a}$, Image of a dopamine neuron taken with a two-photon microscope, illustrating the location of the labeled iontophoretic dopamine pipette used to activate the currents illustrated on the right. The cell was imaged using an internal solution containing Alexa Fluor488 $(2 \mu \mathrm{m})$. The iontophoretic pipette included sulforhodamine $101(300 \mu \mathrm{m}$ ). The fine tip of the iontophoretic electrode (not clearly visible) was placed $\sim 1-2 \mu \mathrm{m}$ from the plasma membrane in each case. Bar graphs are summarized data showing the average amplitude and time to peak of the outward current induced by dopamine applied to the soma and their dendrites. Dendritic sites were $\geq 50 \mu \mathrm{m}$ from the soma $(n=5)$. $\boldsymbol{b}$, GIRK evoked currents evoked by the iontophoresis of dopamine onto VTA dopamine neurons in the slice and onto nucleated nucleated macro-patches pulled from VTA dopamine neurons (DA $100 \mu \mathrm{m}, 100 \mathrm{~ms}$ ). The currents induced by dopamine applied by iontophoresis or in the patch recordings were blocked by the $\mathrm{D}_{2}$-receptor antagonist sulpiride ( $200 \mathrm{~nm}$ ) but not the $\alpha 2$-receptor antagonist idazoxan (1 $\mu \mathrm{m}$ ) (iontophoretic experiments, $n=6$; patch experiments sulpiride $n=5$, idazoxan $n=3$ ). $c$, Summarized data illustrating the pharmacological block of $\mathrm{D}_{2}$-receptors.

profile) confirmed that dopamine was detected following stimulation (reduction peak of evoked release: $-379 \pm 7 \mathrm{mV}, n=9$; versus the reduction peak of exogenous dopamine: $-358 \pm 9$ $\mathrm{mV}, n=3$ ) (Fig. 1d). The voltammogram did not match that produced by the exogenous application of serotonin (data not shown). Thus serotonin was most likely not released in the VTA with our stimulation protocol and does not contribute to the generation of the $\mathrm{D}_{2}$-IPSC. Like the single stimulation, the train of five stimuli evoked a rise in the concentration of extracellular dopamine $\left([\mathrm{DA}]_{\mathrm{o}}\right)$ that peaked before the $\mathrm{D}_{2}$-IPSC (Fig. 1b). The time to peak for the $[\mathrm{DA}]_{\mathrm{o}}$ was $244 \pm 26 \mathrm{~ms}(n=17)$, which was faster than that of the IPSC ( $374 \pm 15 \mathrm{~ms} ; n=17 ; p=0.0001$; measured from the first stimulus of the train) (Fig. 1b).

Following stimulation the $\mathrm{D}_{2}$-IPSC decayed to baseline with a time course that preceded the extracellular FSCV dopamine transient. This was most likely due to an underestimate of the rate of clearance of extracellular dopamine by voltammetry (Bath et al., 2000). This temporal distortion does not occur with amperometry, where a constant positive potential is applied to the carbon fiber so that it does not promote adsorption of cationic species.
Due to the decreased sensitivity of amperometry, a train of stimuli was used. The decay in $[D A]_{0}$, measured with amperometry, was faster than the IPSC $(n=12)$ (Fig. 1b), indicating that the duration of the $[\mathrm{DA}]_{\mathrm{o}}$ transient was less than the IPSC (duration to within $80 \%$ of baseline amperometry: $542 \pm 39 \mathrm{~ms}, n=12$; vs IPSC: $858 \pm 48 \mathrm{~ms}, n=17, p=0.0001$ ) (Fig. 1c).

Based on the size of the carbon fiber, dopamine was measured in the extracellular space from numerous release sites. The distance from each release site to the probe will affect the time required for dopamine to reach the probe. Despite the spatial and temporal limitations of measuring the bulk dopamine transient in the extracellular space, the rise and fall in dopamine occurred more rapidly than the IPSC. Thus, a transient exposure of dopamine at postsynaptic $\mathrm{D}_{2}$ receptors mediates the IPSC.

\section{High concentrations of dopamine are required to mimic the IPSC}

The dopamine transient measured in the extracellular space with the carbon fiber most likely represents an underestimate of the concentration of dopamine at postsynaptic $\mathrm{D}_{2}$ receptors that mediate the IPSC. To determine the concentration and duration of dopamine at the receptor it was necessary to apply a known concentration of dopamine for a controlled period. Due to diffusion barriers this was not possible using brain slices. Therefore, the current induced by dopamine was examined using outside-out nucleated macro-patches from VTA cells. Patches were pulled from the soma of dopamine neurons and positioned out from the slice directly in front of a flow pipe constructed from theta tubes. One barrel contained control saline, while the other contained known concentrations of dopamine. The flow pipe was attached to a piezoelectric bimorph for rapid exchange of the two solutions $(0.9 \pm 0.2 \mathrm{~ms}, 10-90 \%$ rise time) (Fig. $2 a$, inset).

The amplitude and the kinetics of the current activated by dopamine were dependent on concentration. Applications of 250 ms were examined initially as this was similar to the time course of extracellular dopamine measured with amperometry when evoked with a single stimulation (Fig. $2 a$, inset). A low concentration of dopamine $(100 \mathrm{nM})$ evoked a small current in three out of 10 patches ( $6 \pm 1 \mathrm{pA} ; n=3$ of 10) (Fig. $2 a, c)$. The rate of activation and amplitude of these currents were slower than the IPSC (time to $10 \%$ of the peak patch: $282 \pm 10 \mathrm{~ms} ; n=3$; time to $10 \%$ of the peak IPSC: $87 \pm 4 \mathrm{~ms}, n=28 ; p<0.0001$ ) (Fig. $2 b, d$ ). Increasing the concentration of dopamine tenfold $(1 \mu \mathrm{M})$ evoked larger currents that exhibited a faster rate of activation (amplitude $1 \mu \mathrm{M}, 250 \mathrm{~ms}: 32 \pm 2 \mathrm{pA}, n=7$ out of 12 patches). However, the kinetics and amplitude of the current induced by DA $(1 \mu \mathrm{M})$ were also slow relative to the IPSC (time to $10 \%$ peak $1 \mu \mathrm{M}, 250$ 
ms patch: $156 \pm 15 \mathrm{~ms} ; p=0.002$ ) (Fig. $2 a, b$ ). Increasing the concentration of dopamine to $10 \mu \mathrm{M}$ increased the amplitude and decreased the delay until the activation of the current (amplitude $52 \pm 7 \mathrm{pA}$, time to $10 \%$ peak $101 \pm 6 \mathrm{~ms}, n=12, p<$ $0.05)$. Increasing the concentration to $100 \mu \mathrm{M}$ evoked rapidly activating currents that were similar to the IPSC (amplitude $65 \pm$ $11 \mathrm{pA}$, time to $10 \%$ peak $92 \pm 6 \mathrm{~ms}, n=13, p>0.4$ ) (Fig. $2 a, c$ ).

The major effect of increasing the concentration of dopamine to $100 \mu \mathrm{M}$ was that currents could be evoked with short applications. The high concentration of dopamine $(100 \mu \mathrm{M})$ evoked a current that activated with a similar rate of activation regardless of the duration of application (Fig. 2d). Decreasing the concentration of dopamine $(10 \mu \mathrm{M})$ also evoked kinetically similar currents (Fig. $2 d$ ). However, at this concentration, a longer duration (25 $\mathrm{ms}$ ) of dopamine application was required and currents could only be observed in half of the patches (Fig. $2 c, d$ ). Regardless of the duration of dopamine applied, low concentrations of dopamine $(100 \mathrm{nM}-1 \mu \mathrm{M})$ failed to evoke currents that kinetically matched the rate of activation of the $\mathrm{D}_{2}$-IPSC. These results suggest that the minimum concentration present at postsynaptic $\mathrm{D}_{2}$ receptors during the peak of the IPSC is $\geq 10 \mu \mathrm{M}$. While lower concentrations of dopamine evoked outward currents, the rate of activation was slower than the IPSC. Thus, although $\mathrm{D}_{2}$ receptors exhibit a high affinity for dopamine (Richfield et al., 1989; Stormann et al., 1990), a much higher concentration was required to produce the rapid activation of receptors to kinetically match that seen during transmission.

To confirm that the activation kinetics of the potassium conductance was similar at different sites in the neuron, dopamine $/ \mathrm{D}_{2}$ receptor signaling in the soma and dendritic arbor was next examined. Dopamine was applied by iontophoresis at somatic and dendritic ( $>50 \mu \mathrm{m}$ from the soma) locations. Dopamine neurons were filled with Alexa Fluor $594(1 \mu \mathrm{M})$ and visualized using a 2 -photon microscope (Fig. $3 a$ ). The outward current evoked from dendrites was smaller in amplitude than the current evoked in the cell body (amplitude soma $142 \pm 25 \mathrm{pA}$; $n=5$; amplitude dendrites $91 \pm 20 \mathrm{pA} ; n=5 ; p<0.05$ ) (Fig. $3 a$ ), but the kinetics of the current recorded in both sites were similar (time to peak soma: $575 \pm 37 \mathrm{~ms} ; n=5$; time to peak dendrites: $691 \pm 67 \mathrm{~ms} p>0.1$ ) (Fig. $3 a$ ). Both the $\mathrm{D}_{2}$-IPSC and the current induced by iontophoretic application of dopamine are mediated by $\mathrm{D}_{2}$ receptors (Beckstead et al., 2004). The current produced by dopamine applied by iontophoresis to the soma was also blocked by sulpiride ( $200 \mathrm{nM} ; n=6 ; 6 \pm 4 \%$ of control) (Fig. $3 b, c)$ and not blocked by $\alpha$-2-adrenoceptor antagonist, idazoxan ( $1 \mu \mathrm{M} ; n=6$; $102 \pm 5 \%$ of control) (Fig. $3 b, c$ ). Finally, the dopamine-evoked current measured in nucleated patches was blocked by sulpiride ( $200 \mathrm{nM} ; n=5 ; 7 \pm 2 \%$ of control) (Fig. $3 b, c$ ) and not blocked by $\alpha$-2-adrenoceptor antagonist, idazoxan ( $1 \mu \mathrm{M} ; n=3 ; 100 \pm 16 \%$ of control) (Fig. $3 b, c)$. This confirmed that the dopamine current recorded in nucleated patches resulted from the activation of $\mathrm{D}_{2}$-receptors that are kinetically similar to those receptors mediating the IPSC.

\section{The period of $D_{2}$ receptor activation determines the time course of transmission}

To further examine the time course of $\mathrm{D}_{2}$ receptor activation, dopamine $(100 \mu \mathrm{M})$ was applied to nucleated macro-patches for various durations to determine the minimum time course of $\mathrm{D}_{2}$ receptor/GIRK signaling. Increasing the duration of application from 5 to $100 \mathrm{~ms}$ evoked larger amplitude currents (amplitude: 5 $\mathrm{ms}=12 \pm 2 \mathrm{pA} ; n=9 ; 100 \mathrm{~ms}=37 \pm 5 \mathrm{pA}, n=14 ; p=0.001)$ that peaked with a similar latencies (time to peak $5 \mathrm{~ms}=215 \pm 17$

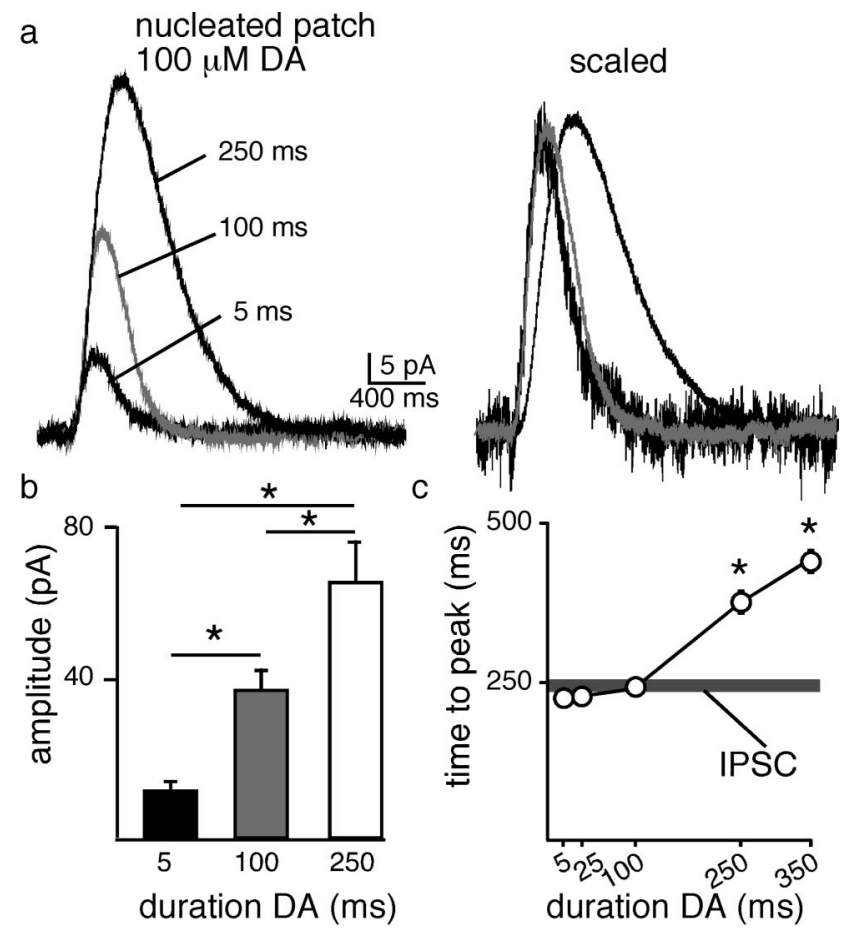

d D2-IPSC

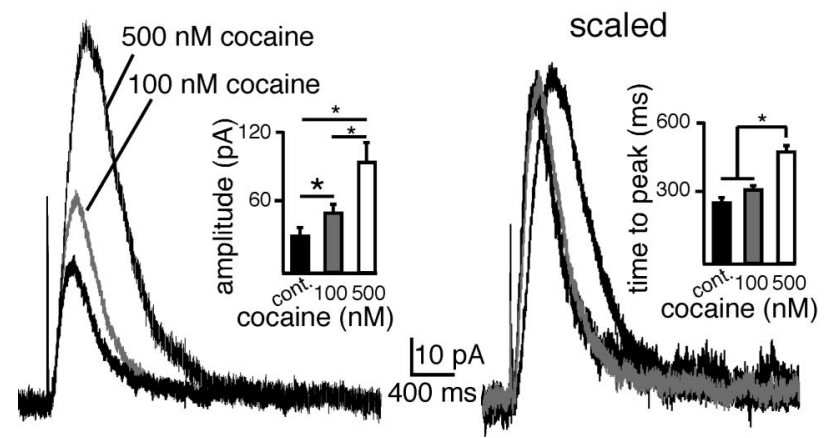

Figure 4. Intrinsic time course of $D_{2}$-receptor activation of GIRK current. $\boldsymbol{a}$, Dopamine (100 $\mu \mathrm{m})$ evoked GIRK currents from nucleated patches. Increasing the duration of application produced an increase in amplitude. Applications ranging from 5 to $100 \mathrm{~ms}$ did not change the time course of the outward current as indicated by the currents after being scaled to the peak. Application of dopamine for $250 \mathrm{~ms}$ activated a larger current that reached a peak later than currents induced by short applications of dopamine. $\boldsymbol{b}$, Summary illustrating the increase in amplitude for $5 \mathrm{~ms}(n=9), 100 \mathrm{~ms}(n=14)$ and $250 \mathrm{~ms}(n=13)$ applications of dopamine. c, Summary illustrating the time to peak after application of dopamine (100 $\mu \mathrm{M})$ for various durations. Horizontal dark gray bar represents the mean \pm SEM of the time to peak of IPSC evoked from a single pulse. $\boldsymbol{d}$, Representative traces illustrating the effect of cocaine on $D_{2}$-IPSCS. Low concentrations of cocaine $(100 \mathrm{~nm})$ increased the amplitude but not the time to peak of the IPSC $(n=9)$, while higher concentrations $(500 \mathrm{~nm}, n=8)$ further increased the amplitude and also the time to peak.

$\mathrm{ms}, n=9 ; 100 \mathrm{~ms}=239 \pm 9 \mathrm{~ms} ; n=14 ; p>0.8)$ (Fig. $4 a-c$ ). Thus, applications of dopamine $(100 \mu \mathrm{M})$ for 5,25 , or $100 \mathrm{~ms}$ produced currents that, when scaled to the peak amplitude, were super imposable (Fig. 4a). To mimic the time to peak of the $\mathrm{D}_{2}$-IPSC evoked from a single stimulation, the maximum time that dopamine $(100 \mu \mathrm{M})$ could be applied was $100 \mathrm{~ms}$ (time to peak $100 \mathrm{~ms}=239 \pm 9 \mathrm{~ms}, n=14$, time to peak IPSC $=255 \pm$ $38 \mathrm{~ms} n=28, p>0.5$ ) (Fig. $4 c$ ). An application of dopamine for $250 \mathrm{~ms}$ evoked a current that took $373 \pm 16 \mathrm{~ms}$ to peak $(n=13)$, significantly longer than the IPSC and the current induced by a $100 \mathrm{~ms}$ application ( $p=0.0005)$. This places an upper limit on the duration of the peak concentration of dopamine that medi- 
a nucleated patch
(5 ms)

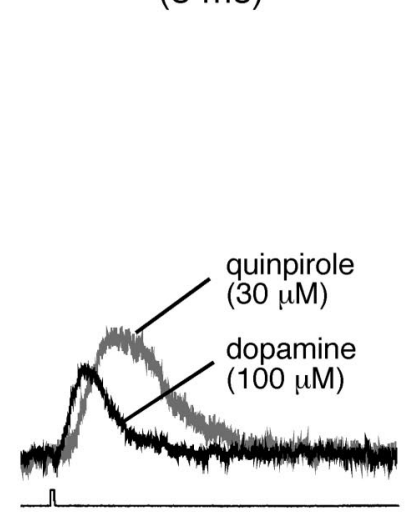

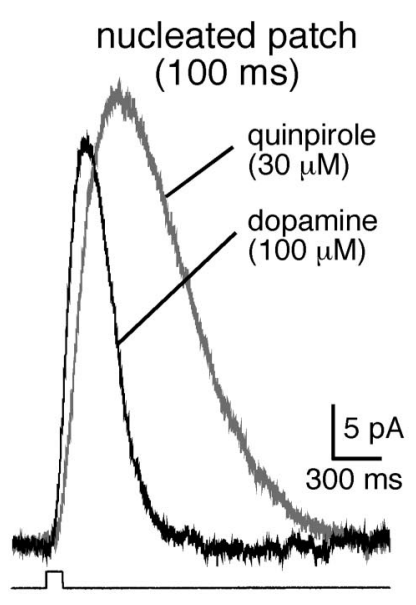

b

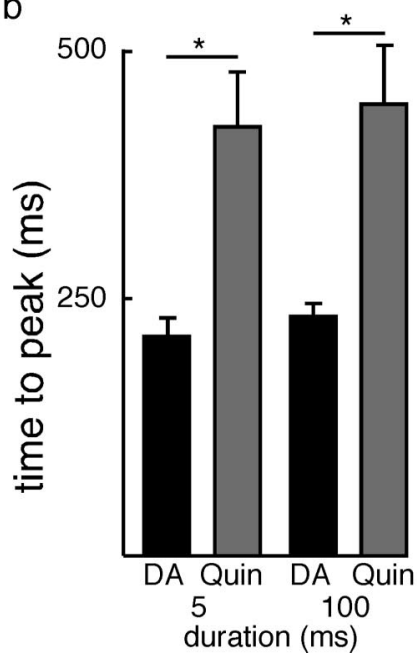

C

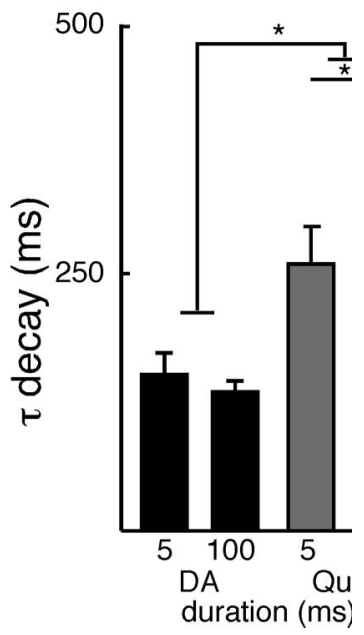

Figure 5. Kinetics of currents induced by $\mathrm{D}_{2}$ receptors are agonist dependent. $\boldsymbol{a}$, Currents evoked with 5 or $100 \mathrm{~ms}$ application of dopamine (100 $\mu \mathrm{M}$ ) or quinpirole ( $\left.30 \mu \mathrm{M}\right)$. Quinpirole evoked a current that rose to peak later than a similar application of dopamine. The time course of decay of the current induced by quinpirole was also slower. $\boldsymbol{b}$, Summarized data illustrating the time peak, dopamine $(n=15)$, quinpirole $(n=7) .{ }^{*} p<0.0001$. c, Summarized data illustrating the time constant of decay ( $\tau$ decay) of dopamine $(n=15)$ and quinpirole $(n=7) .{ }^{*} p<0.0001$.

a

$$
\text { D2-IPSC }
$$
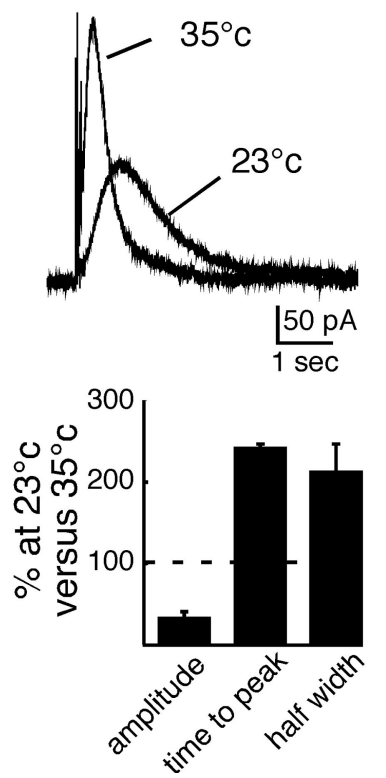

b nucleated patch $(100 \mu \mathrm{M}, 100 \mathrm{~ms})$
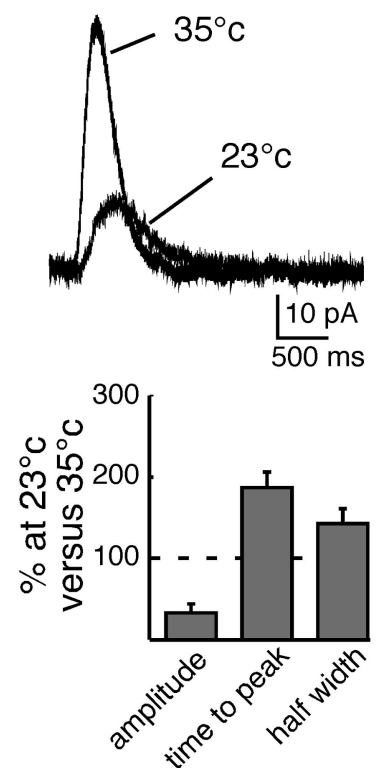

C
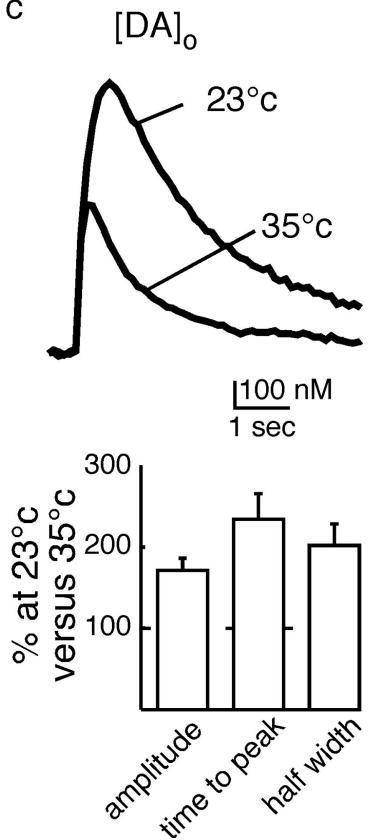

Figure 6. Low temperature decreases the amplitude and increases the duration of the IPSC by a postsynaptic mechanism. a, Top, Examples of D2-IPSCs evoked at 35 and $23^{\circ} \mathrm{C}$; bottom, summarized data showing the change in IPSC amplitude, time to peak, and half width induced by lowering the temperature. $\boldsymbol{b}$, Top, Example traces from patch recordings at two temperatures; bottom, summarized data from the patch recording. $c$, Top, Example traces of the extracellular dopamine measured with FSCV in brain slices at two temperatures. Bottom, Summarized data from the FSCV experiment illustrated above.

ates the IPSC. As the duration and time to peak of the current did not vary between 5 and $100 \mathrm{~ms}$, the result suggests that brief exposure to dopamine results in a fixed period of $\mathrm{D}_{2}$-receptor/Gprotein/GIRK channel activation. It is this intrinsic period of receptor signaling, not the presence of dopamine that determines the time course of the peak of the IPSC.

If the IPSC was mediated by a dopamine transient that was $<100 \mathrm{~ms}$, a small increase in the presence of dopamine could increase the amplitude without altering the kinetics of the IPSC. The presence of dopamine was increased by blocking dopamine uptake with cocaine. In the presence of a low concentration of co- caine (100 nM, $n=9)$, the amplitude of the $\mathrm{D}_{2}$-IPSC was increased $163 \pm 7 \%(n=$ $9, p=0.01$ ), yet the kinetics remained unchanged ( $p>0.1$ ) (Fig. $4 d$ ). A higher concentration of cocaine ( $500 \mathrm{nM}, n=8$ ) further increased the amplitude $(283 \pm$ $25 \%, n=8, p=0.005)$, the time to peak (138 $\pm 4 \%, n=8, p=0.001)$, and the decay of the $\mathrm{D}_{2}$-IPSC (Fig. $4 d$ ). Together with the patch recordings, the results suggest that dopamine mediating the $\mathrm{D}_{2}$ IPSC was present at $\mathrm{D}_{2}$ receptors for no longer than $100 \mathrm{~ms}$.

\section{The kinetics of GPCR signaling are agonist dependent}

The results indicate that the time course of the IPSC was limited by the kinetics of receptor activation. To distinguish receptor activation from the activation of the GIRK conductance, the outward current evoked by the rapid application of the synthetic agonist quinpirole was examined. Quinpirole has a higher affinity for the $\mathrm{D}_{2}$ receptor than dopamine (Levant et al., 1992), and was therefore predicted to result in currents that were prolonged relative to the current induced by dopamine. A concentration of quinpirole $(30 \mu \mathrm{M})$ was chosen that evoked a maximal outward current ( $100 \mathrm{~ms}: 41 \pm 4 \mathrm{pA}, n=7)$. The application of quinpirole $(30 \mu \mathrm{M}, 100 \mathrm{~ms})$ evoked a current that had a longer latency to activate (time to $10 \%$ of the peak: $119 \pm 4 \mathrm{~ms}, n=7$ ) and peaked later $(437 \pm 8 \mathrm{~ms}, n=7, p<0.0001)$ than the current induced by dopamine $(100 \mu \mathrm{M}, 82.5 \pm 5 \mathrm{~ms}, n=15, p<0.0001)$ (Fig. $5 a, b)$. In addition, the time constant of the decay $\left(\tau_{\text {decay }}\right)$ of the current induced by quinpirole $(30 \mu \mathrm{M}, 100 \mathrm{~ms}: 397 \pm 40 \mathrm{~ms}$, $n=7)$ was greater than dopamine $(100 \mu \mathrm{M}, 100 \mathrm{~ms}: 138 \pm 11 \mathrm{~ms}$, $n=15, p<0.0001$ ) (Fig. 5a,c). This suggests that both the on-rate $\left(\mathrm{K}_{\mathrm{on}}\right)$ and off-rate $\left(\mathrm{K}_{\mathrm{off}}\right)$ were slower than dopamine. Thus, the time 
course of the IPSC is determined by the kinetics of dopamine- $\mathrm{D}_{2}$ receptor interaction.

\section{The temperature dependence of dopamine transmission}

To further examine the signaling processes underlying the dopamine transmission, the release of dopamine, the $\mathrm{D}_{2}$-IPSC, and the current measured in excised patches at $35^{\circ} \mathrm{C}$ and $23^{\circ} \mathrm{C}$ were examined. Decreasing the temperature was expected to have relatively minor effects on the kinetics of free diffusion of dopamine compared to intracellular signaling. At $23^{\circ} \mathrm{C}$, the amplitude of the IPSC and current evoked in nucleated patches was decreased $\left(\mathrm{D}_{2}\right.$-IPSC decreased to $34 \pm$ $6 \% ; n=6, p<0.01$; nucleated patches decreased to $33 \pm 9 \% ; n=9 ; p<0.01$ ). However, the amount of extracellular dopamine measured electrochemically increased by $170 \pm 13 \%(n=6, p<0.05)$ (Fig. 6). Despite the differences on the effects of amplitude, the kinetics of all three measurements were slowed at $23^{\circ} \mathrm{C}$ (half maximal duration $[\mathrm{DA}]_{\mathrm{o}}: 201 \pm 23 \%, n=$ $6 ; p<0.05 ; D_{2}$-IPSCs: $226 \pm 14 \%, n=6$, $p<0.05$; nucleated patch: $143 \pm 16 \%$, $n=9$ ) (Fig. 6). As the amplitude and kinetics of the IPSC and the direct application of dopamine were both reduced at room temperature, the results indicate that the intracellular signaling cascade, not the extracellular diffusion of dopamine, limited the time course of the IPSC.

\section{A second component underlies the late-phase of the IPSC}

The $\mathrm{D}_{2}$-IPSC had a longer duration than the current measured in outside-out patch recordings (Fig. 7a). Simply increasing the duration of dopamine application to patches did not change the kinetics of the current in a way that matched the IPSC (Fig. $4 c$ ). The presence of a late component of the IPSC suggests that receptor activation may be prolonged. Two (not mutually exclusive) possibilities exist that could explain the late component of the IPSC. Dopamine could diffuse some distance and recruit additional receptors, or the concentration of dopamine could decrease slowly over time resulting in a prolonged activation of local $\mathrm{D}_{2}$ receptors (Fig. $7 b$ ). While these two possibilities could not be distinguished, it was possible to qualitatively replicate the $\mathrm{D}_{2}$-IPSC by adding the current produced by a brief high concentration of dopamine (100 ms, $100 \mu \mathrm{M}$; red trace) to the current produced by a prolonged low concentration (500 ms, $100 \mathrm{~nm}$; gray trace) (Fig. $7 c, d$ ). Thus, although a low concentration of dopamine may contribute to the late phase of the IPSC, a high concentration is required to induce the rising phase of the IPSC.

\section{Discussion}

This study compares the kinetics of $\mathrm{D}_{2}$-receptor mediated activation of potassium conductance induced by dopamine applied to outside-out patches with the $\mathrm{D}_{2}$-receptor dependent IPSC measured in brain slices. When dopamine $(10-100 \mu \mathrm{M})$ was applied for $100 \mathrm{~ms}$ the current rose to a peak in $\sim 250 \mathrm{~ms}$ and declined within $\sim 500 \mathrm{~ms}$ to baseline. The duration of the current did not decrease further even when dopamine was applied for $5 \mathrm{~ms}$. Thus, b

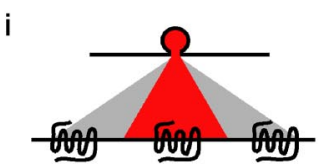

ii

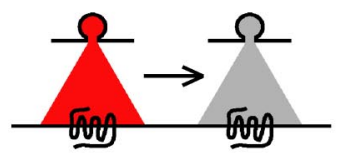

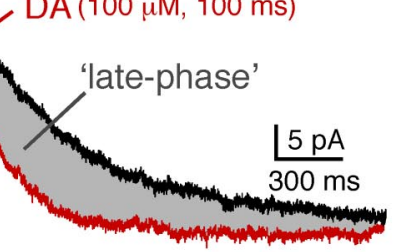

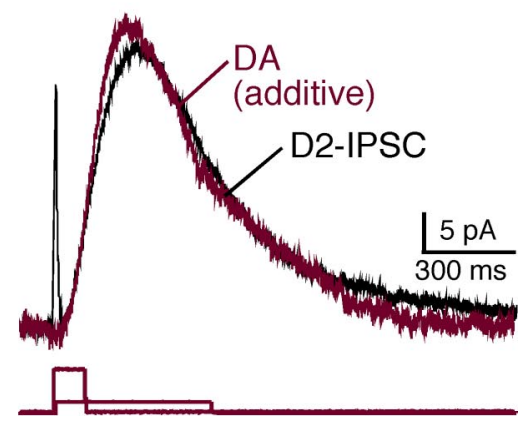

$\mathrm{A}(100 \mu \mathrm{M}, 100 \mathrm{~ms})$

A (100 nM, $500 \mathrm{~ms})$

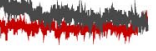

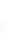
Figure 7. Schematic illustrating how the release of dopamine may mediate the IPSC. $\boldsymbol{a}$, Comparison of the $\mathrm{D}_{2}$-IPSC (black) with
the current evoked by dopamine (100 $\mu \mathrm{m}, 100 \mathrm{~ms}$, red). The duration of the IPSC is longer than the current evoked by a brief is the sum of the short (red) and long (gray) traces from the experiment shown on the left. The traces below are the open tip of application of dopamine.

the current in the patch recordings induced by dopamine (10-100 $\mu \mathrm{M}$ ) applied for $100 \mathrm{~ms}$ or less, mimicked the early component of the dopamine-IPSC. The most conservative interpretation is that the IPSC is activated by a concentration of dopamine that is $\geq 10 \mu \mathrm{M}$ that is present for $\leq 100 \mathrm{~ms}$. The results challenge the hypothesis that dendritic release of dopamine activates receptors through a mechanism involving diffusion over a great distance.

\section{Transmitter diffusion and receptor affinity}

Synaptic transmission mediated by GPCRs has been described in multiple sites in the nervous system. The majority of studies have focused on $\mathrm{GABA}_{\mathrm{B}}$ receptors. These receptors are most often located at extra-synaptic sites (Kulik et al., 2002; López-Bendito et al., 2002). The high affinity of $\mathrm{GABA}_{\mathrm{B}}$ receptors allows for their activation at the lower concentrations of agonist found at these extra-synaptic sites (Otis and Mody, 1992; Isaacson et al., 1993; Sodickson and Bean, 1996; Scanziani, 2000). Pooling of GABA from multiple release sites in the extracellular space is then though to be important for the activation of $\mathrm{GABA}_{\mathrm{B}}$ IPSCs (Scanziani, 2000). This may account for the necessity to use multiple stimuli to evoke $\mathrm{GABA}_{\mathrm{B}}$ mediated synaptic potentials (Otis and Mody, 1992; Isaacson et al., 1993; Scanziani, 2000).

The ability to measure dopamine in the extracellular space with high temporal fidelity by electrochemical means has allowed estimation of the diffusion of dopamine in the extracellular space (Garris et al., 1994; Cragg and Rice, 2004; Staal et al., 2004; Rice and Cragg, 2008). At both dendritic (SNc) and terminal (striatum) release sites, pooling of dopamine in the extracellular space is thought to allow dopamine to signal over a large area (Garris et al., 1994; Cragg and Rice, 2004; Staal et al., 2004; Rice and Cragg, 2008). Anatomical studies have found that $D_{2}$ receptors are primarily located at extrasynaptic sites, lending support to the hypothesis that dopamine may signal at a distance from multiple 
sources (Sesack et al., 1994; Pickel et al., 2002). However, unlike reports in terminal regions, the density of release sites and distance from the release site to $\mathrm{D}_{2}$ receptors has not been anatomically quantified in the VTA.

Amperometric studies using midbrain dopamine neurons in slices and culture have measured events that had rapid kinetics resulting from the fusion of single vesicles (Jaffe et al., 1998; Staal et al., 2004). Other work has shown that the concentration of dopamine decreased exponentially with distance from the release site (Garris et al., 1994). The activation of receptors by dopamine is therefore dependent on the distance that dopamine diffuses and the affinity of postsynaptic receptors (Rice and Cragg, 2008). The affinity of dopamine for the $\mathrm{D}_{2}$ receptor when measured at equilibrium is $\sim 10 \mathrm{~nm}$ (Richfield et al., 1989; Stormann et al., 1990). However, the transient rise in the concentration of transmitter during synaptic transmission does not reach steady-state so that equilibrium binding cannot be used to predict receptor occupation (Clements et al., 1992; Diamond and Jahr, 1997; Beato, 2008). For example, EPSCs mediated by glutamate depend on a concentration $\sim 1000$-fold greater than the $\mathrm{EC}_{50}$ value (Patneau and Mayer, 1990; Clements et al., 1992).

Diffusion of dopamine away from the release site in the substantia nigra has been simulated with radial diffusion models. Those models predict that over a distance of 2 to $8 \mu \mathrm{m}$ from the release site, the peak concentration of dopamine falls from $1 \mu \mathrm{M}$ to $10 \mathrm{~nm}$ (Cragg and Rice, 2004; Rice and Cragg, 2008). The present study indicates that at least $10 \mu \mathrm{M}$ dopamine was required for the phasic activation of $D_{2}$ receptors required to evoke an IPSC. When this concentration was used in combination with the diffusion model, the outcome suggests that synaptically released dopamine acted on receptors within $\sim 1 \mu \mathrm{m}$ of the release site.

\section{The kinetics of GPCRs}

The GPCR-dependent activation of potassium conductance has been examined at several brain regions and in each case the kinetics of the underlying currents are similar (Pan et al., 1989; Otis et al., 1993). Likewise, the activation of a variety of GPCRs using rapid application of saturating concentrations of agonist report a lag before the onset of current that peaks within several hundred milliseconds (Pan et al., 1989; Sodickson and Bean, 1996; Ingram et al., 1997). This most likely represents the time for G-protein activation of the potassium channel (Riven et al., 2006). These values match well with the kinetics of $\mathrm{D}_{2}$ receptor mediated GIRK currents. In the present study, lower concentrations of dopamine resulted in smaller currents that activated with slower kinetics. Similar results have been obtained in a study of the GABA-B receptor activation of potassium current where an $\mathrm{EC}_{50}$ concentration of baclofen activated currents at a rate 3 times slower than with a saturating concentration (Sodickson and Bean, 1996).

To distinguish agonist receptor binding from second messenger signaling, two experiments were performed. First, the temperature of the bath was changed. At low temperature more dopamine remained in the extracellular space for longer, whereas the $\mathrm{D}_{2}$-IPSC and the current induced by application of dopamine to outside-out patches were smaller and slower. The effect of decreased temperature was expected to have a greater effect on the kinetics of intracellular signaling than the free diffusion of dopamine. Thus, the steps subsequent to agonist binding determined the rate of current activation. The second experiment examined the current induced by application of quinpirole to outside-out patches. Quinpirole evoked currents that had a slower rate of rise and decay than dopamine. This suggests that the higher affinity of quinpirole for the $\mathrm{D}_{2}$ receptor lead to pro- longed receptor activation (Levant et al., 1992). The fact that the current induced by the two agonists was different suggests that the on and off rates of the two agonists regulate the macroscopic current. Thus, the specific interaction between agonist and the $\mathrm{D}_{2}$ receptor, as well as second messenger signaling, are key determinants regulating the time course of the $\mathrm{D}_{2}$-IPSC.

\section{References}

Balakrishnan V, Kuo SP, Roberts PD, Trussell LO (2009) Slow glycinergic transmission mediated by transmitter pooling. Nat Neurosci 12:286-294.

Barbour B, Keller BU, Llano I, Marty A (1994) Prolonged presence of glutamate during excitatory synaptic transmission to cerebellar Purkinje cells. Neuron 12:1331-1343.

Bath BD, Michael DJ, Trafton BJ, Joseph JD, Runnels PL, Wightman RM (2000) Subsecond adsorption and desorption of dopamine at carbonfiber microelectrodes. Anal Chem 72:5994-6002.

Beato M (2008) The time course of transmitter at glycinergic synapses onto motoneurons. J Neurosci 28:7412-7425.

Beckstead MJ, Grandy DK, Wickman K, Williams JT (2004) Vesicular dopamine release elicits an inhibitory postsynaptic current in midbrain dopamine neurons. Neuron 42:939-946.

Björklund A, Lindvall O (1975) Dopamine in dendrites of substantia nigra neurons: suggestions for a role in dendritic terminals. Brain Res 83:531-537.

Chen BT, Rice ME (2001) Novel $\mathrm{Ca}^{2+}$ dependence and time course of somatodendritic dopamine release: substantia nigra versus striatum. J Neurosci 21:7841-7847.

Chen BT, Moran KA, Avshalumov MV, Rice ME (2006) Limited regulation of somatodendritic dopamine release by voltage-sensitive Ca channels contrasted with strong regulation of axonal dopamine release. J Neurochem 96:645-655.

Cheramy A, Leviel V, Glowinski J (1981) Dendritic release of dopamine in the substantia nigra. Nature 289:537-542.

Clements JD, Lester RA, Tong G, Jahr CE, Westbrook GL (1992) The time course of glutamate in the synaptic cleft. Science 258:1498-1501.

Cragg SJ, Rice ME (2004) DAncing past the DAT at a DA synapse. Trends Neurosci 27:270-277.

Diamond JS, Jahr CE (1995) Asynchronous release of synaptic vesicles determines the time course of the AMPA receptor-mediated EPSC. Neuron 15:1097-1107.

Diamond JS, Jahr CE (1997) Transporters buffer synaptically released glutamate on a submillisecond time scale. J Neurosci 17:4672-4687.

Ford CP, Mark GP, Williams JT (2006) Properties and opioid inhibition of mesolimbic dopamine neurons vary according to target location. J Neurosci 26:2788-2797.

Ford C, Beckstead MJ, Williams JT (2007) Kappa opioid inhibition of somatodendritic inhibitory postsynaptic currents. J Neurophysiol 97:883891

Garris PA, Ciolkowski EL, Pastore P, Wightman RM (1994) Efflux of dopamine from the synaptic cleft in the nucleus accumbens of the rat brain. J Neurosci 14:6084-6093.

Geffen LB, Jessell TM, Cuello AC, Iversen LL (1976) Release of dopamine from dendrites in rat substantia nigra. Nature 260:258-260.

Grace AA, Onn SP (1989) Morphology and electrophysiological properties of immunocytochemically identified rat dopamine neurons recorded in vitro. J Neurosci 9:3463-3481.

Huang CL, Slesinger PA, Casey PJ, Jan YN, Jan LY (1995) Evidence that direct binding of $\mathrm{G}$ beta gamma to the GIRK1 G protein-gated inwardly rectifying $\mathrm{K}+$ channel is important for channel activation. Neuron 15:1133-1143.

Ingram S, Wilding TJ, McCleskey EW, Williams JT (1997) Efficacy and kinetics of opioid action on acutely dissociated neurons. Mol Pharmacol 52:136-143.

Isaacson JS, Solís JM, Nicoll RA (1993) Local and diffuse synaptic actions of GABA in the hippocampus. Neuron 10:165-175.

Jaffe EH, Marty A, Schulte A, Chow RH (1998) Extrasynaptic vesicular transmitter release from the somata of substantia nigra neurons in rat midbrain slices. J Neurosci 18:3548-3553.

Katz B, Miledi R (1973) The binding of acetylcholine to receptors and its removal from the synaptic cleft. J Physiol 231:549-574.

Kofuji P, Davidson N, Lester HA (1995) Evidence that neuronal G-proteingated inwardly rectifying $\mathrm{K}+$ channels are activated by $\mathrm{G}$ beta gamma 
subunits and function as heteromultimers. Proc Natl Acad Sci U S A 92:6542-6546.

Kulik A, Nakadate K, Nyíri G, Notomi T, Malitschek B, Bettler B, Shigemoto R (2002) Distinct localization of GABA(B) receptors relative to synaptic sites in the rat cerebellum and ventrobasal thalamus. Eur J Neurosci 15:291-307.

Lammel S, Hetzel A, Häckel O, Jones I, Liss B, Roeper J (2008) Unique properties of mesoprefrontal neurons within a dual mesocorticolimbic dopamine system. Neuron 57:760-773.

Lester RA, Clements JD, Westbrook GL, Jahr CE (1990) Channel kinetics determine the time course of NMDA receptor-mediated synaptic currents. Nature 346:565-567.

Levant B, Grigoriadis DE, DeSouza EB (1992) Characterization of [3H]quinpirole binding to D2-like dopamine receptors in rat brain. J Pharmacol Exp Ther 262:929-935.

Logothetis DE, Kurachi Y, Galper J, Neer EJ, Clapham DE (1987) The beta gamma subunits of GTP-binding proteins activate the muscarinic $\mathrm{K}+$ channel in heart. Nature 325:321-326.

López-Bendito G, Shigemoto R, Kulik A, Paulsen O, Fairén A, Luján R (2002) Expression and distribution of metabotropic GABA receptor subtypes GABABR1 and GABABR2 during rat neocortical development. Eur J Neurosci 15:1766-1778.

Lüscher C, Jan LY, Stoffel M, Malenka RC, Nicoll RA (1997) G proteincoupled inwardly rectifying $\mathrm{K}+$ channels (GIRKs) mediate postsynaptic but not presynaptic transmitter actions in hippocampal neurons. Neuron 19:687-695.

Mozrzymas JW, Barberis A, Mercik K, Zarnowska ED (2003) Binding sites, singly bound states, and conformation coupling shape GABA-evoked currents. J Neurophysiol 89:871-883.

Nirenberg MJ, Chan J, Liu Y, Edwards RH, Pickel VM (1996) Ultrastructural localization of the vesicular monoamine transporter-2 in midbrain dopaminergic neurons: potential sites for somatodendritic storage and release of dopamine. J Neurosci 16:4135-4145.

Otis TS, Mody I (1992) Differential activation of GABAA and GABAB receptors by spontaneously released transmitter. J Neurophysiol 67: 227-235.

Otis TS, De Koninck Y, Mody I (1993) Characterization of synaptically elicited $G A B A B$ responses using patch-clamp recordings in rat hippocampal slices. J Physiol 463:391-407.

Overstreet LS, Jones MV, Westbrook GL (2000) Slow desensitization regulates the availability of synaptic $\mathrm{GABA}_{\mathrm{A}}$ receptors. J Neurosci 20:7914-7921.

Pan ZZ, Colmers WF, Williams JT (1989) 5-HT-mediated synaptic potentials in the dorsal raphe nucleus: interactions with excitatory amino acid and GABA neurotransmission. J Neurophysiol 62:481-486.
Patneau DK, Mayer ML (1990) Structure-activity relationships for amino acid transmitter candidates acting at $N$-methyl-D-aspartate and quisqualate receptors. J Neurosci 10:2385-2399.

Pickel VM, Chan J, Nirenberg MJ (2002) Region-specific targeting of dopamine D2-receptors and somatodendritic vesicular monoamine transporter 2 (VMAT2) within ventral tegmental area subdivisions. Synapse 45:113-124.

Rice ME, Cragg SJ (2008) Dopamine spillover after quantal release: rethinking dopamine transmission in the nigrostriatal pathway. Brain Res Rev 58:303-313.

Rice ME, Cragg SJ, Greenfield SA (1997) Characteristics of electrically evoked somatodendritic dopamine release in substantia nigra and ventral tegmental area in vitro. J Neurophysiol 77:853-862.

Richfield EK, Penney JB, Young AB (1989) Anatomical and affinity state comparisons between dopamine D1 and D2 receptors in the rat central nervous system. Neuroscience 30:767-777.

Riven I, Iwanir S, Reuveny E (2006) GIRK channel activation involves a local rearrangement of a preformed $G$ protein channel complex. Neuron 51:561-573.

Scanziani M (2000) GABA spillover activates postsynaptic GABA(B) receptors to control rhythmic hippocampal activity. Neuron 25:673-681.

Sesack SR, Aoki C, Pickel VM (1994) Ultrastructural localization of D2 receptor-like immunoreactivity in midbrain dopamine neurons and their striatal targets. J Neurosci 14:88-106.

Sodickson DL, Bean BP (1996) GABAB receptor-activated inwardly rectifying potassium current in dissociated hippocampal CA3 neurons. J Neurosci 16:6374-6385.

Sodickson DL, Bean BP (1998) Neurotransmitter activation of inwardly rectifying potassium current in dissociated hippocampal CA3 neurons: interactions among multiple receptors. J Neurosci 18:8153-8162.

Staal RG, Mosharov EV, Sulzer D (2004) Dopamine neurons release transmitter via a flickering fusion pore. Nat Neurosci 7:341-346.

Stormann TM, Gdula DC, Weiner DM, Brann MR (1990) Molecular cloning and expression of a dopamine D2 receptor from human retina. Mol Pharmacol 37:1-6.

Venton BJ, Troyer KP, Wightman RM (2002) Response times of carbon fiber microelectrodes to dynamic changes in catecholamine concentration. Anal Chem 74:539-546.

Wickman KD, Iñiguez-Lluhl JA, Davenport PA, Taussig R, Krapivinsky GB, Linder ME, Gilman AG, Clapham DE (1994) Recombinant G-protein beta gamma-subunits activate the muscarinic-gated atrial potassium channel. Nature 368:255-257.

Wilson CJ, Groves PM, Fifková E (1977) Monoaminergic synapses, including dendro-dendritic synapses in the rat substantia nigra. Exp Brain Res 30:161-174. 